\title{
Improving Vocabulary Mastery Using Selected Game: Colour Me Colours for EYL Students
}

\author{
Nuridah Nuridah, M Dahlan Bahang \& Fitri Arniati \\ STKIP-YPUP Makassar, Makassar. Indonesia \\ fitriarniati168@gmail.com
}

\author{
ARTICLE HISTORY \\ Received : 2021-04-02 \\ Revised : 2021-04-13 \\ Accepted : 2021-07-21

\section{KEYWORDS} \\ Vocabulary mastery \\ EYL Students \\ Colour Me Colour game \\ Learning strategy
}

\begin{abstract}
The mastery of vocabulary is important and it is a fundamental requirement that influences students' achievement in studying English. However, during the pre-observation, most of students still have a problem with vocabulary mastery. They are difficult to join the lesson well in the classroom, although the teacher explains the material clearly, this seems because they lack of vocabulary. This article aimed to find out whether the selected game i.e., "Colour Me Colours" can improve the students' vocabulary mastery at the Second-grade of SMP YP PGRI 4 Makassar. This pre-experimental involves one pre-test and post-test group with four meetings of treatment between it. The data was collected through vocabulary tests to find out students' scores. Derived from the data analyzed, "Colour Me Colours" game can improve the students' vocabulary mastery. The students' scores had a significant different score in pre-test and post-test. The result of the pre-test (49) was low than post-test $(90,66)$. This result highlighted significant findings that most students were more active and interested in learning vocabulary by using "Colour Me Colours" game.
\end{abstract}

\section{Introduction}

Vocabulary relates to words, the words are the key to learning a language and both of them have a vital function in any language. In many ways, vocabulary enrichment is achieved when students are motivated to learn the target language's words. The mastery of vocabulary is important and learning it is more than just memorizing lists of terms; it is a dynamic process that requires the ability to identify words, remember them at will, and correctly pronounce, spell, and use them while being conscious of their connotations and associations (Wallace, 1982).

People use vocabulary in the form of language to communicate our thoughts, ideas, and so on to others, whether orally or in writing. Vocabulary cannot be discussed apart from four language skills: listening, speaking, reading, and writing. The proficiency of someone's speaking and influenced by their vocabulary. Lo, Anderson and Bunch-Crump (2016) add that the need to simultaneously learn academic material and gain English language proficiency while being challenged to read in a language in which they are not fully fluent is a specific challenge for many English learners. Vocabulary is a fundamental requirement that influences students' achievement in studying English. Without Vocabulary, no communication can be delivered, so that it is important to know what the vocabulary is. Karmila (2008, p.78) states that in learning English, vocabulary is the most important that must be a priority before going to another subject.

However, most SMP YP PGRI 4 Makassar students still have a problem with vocabulary mastery in the preobservation period. They are difficult to join the lesson well in the classroom, although the teacher explains the material clearly because they lack of vocabulary. Sometimes, they are lazy to study in the classroom because they do not understand what the teacher explains in front of the class. The students have difficulties in the common regular verb. When they want to borrow a pen or book from their friends in classroom activities, they said it in Indonesian. In the other case, the teacher asked one of them to clean the whiteboard, and they did nothing because they had no idea what the teacher said.

To improve the students' vocabulary, the English teacher must apply some techniques, strategies, or methods applied to the students and one of them through the game (Iriyani, 2008). Therefore, in his research, Febriyansyah (2015) found that most students' vocabulary mastery improved after Bingo Game was used in the teaching and learning process. It was indicated by the increase of the mean of students' vocabulary score in the pre-test and post-test $(64,3$ to $89,1)$. During the game's implementation, students' participation and classroom engagement were 
enhanced. During the game, students demonstrated their excitement by attempting to be the first to win, which increased competition among them. In addition, the implementation of the Bingo Game and the complementary actions were successful in helping the students memorize and understand new words easily. Further, Pajo, 2017; Wulanjani, 2016; Hidayat (2016) underlie the similar things that games helped the students understand vocabulary fast and easily.

All four of the researchers listed above used games to study vocabulary. Previous studies have used vocabulary games and word games to help students develop their vocabulary skills. Based on the explanation above, the researcher concluded that students' learning processes required interesting and enjoyable learning strategies. So the researcher tried another strategy by using the "Colour Me Colour" game method to improve students' vocabulary skills, especially in learning countable and uncountable nouns. Therefore this study tries to highlight a major question, "Does the 'Colour Me Colours' game improve the students' vocabulary mastery?" This research aims to find out whether or not the game can improve students' vocabulary mastery of second-grade students of SMP YP PGRI 4 Makassar.

According to Linguistics ESL Games, the "Colour Me Colours" facilitates students in understanding vocabulary. The game can be applied in a variety of student classes, including kindergarten. Furthermore, no exception can also be applied in the senior high school class and junior high school. The Colour $\mathrm{Me}$ Colours game is a game used by an English teacher for students to remember and understand vocabulary easily. This game is as simple as to use cards that have been coloured by the teacher concerned. In essence, the "Colour Me Colours" game can assists students to memorize vocabulary easily by playing Colour $\mathrm{Me}$ Colour with card instruments. Furthermore, according to Jean in Prasetio, a Color game is a color card in an image or likeness of an object, human, or scene produced on a flat surface, especially by painting, drawing, or photography. Therefore, it is expected to develop knowledge through the game, especially in the English language, and obtain optimal learning outcomes in vocabulary skills to understand and reference for further research. Moreover, as well as to give helpful information to the English teachers of SMP YP PGRI 4 Makassar and wherever they are so that they can use this game as one of the references to improve their vocabulary.

\section{Method}

This pre-experimental design tries to find out the achievement through the "Colour Me Colours" game in teaching vocabulary to the second-grade students of junior high school of SMP YP PGRI 4 Makassar. The population of this research was the students of the second-grade at SMP YP PGRI 4 Makassar. It consisted of one class, and the population was 24 students. This research will choose one class as the sample, consisting of 15 students because they have a low skill of vocabulary mastery.

The instrument of this research was multiple choices of pre-test and post-test. The test consisted of 20 items of multiple choice. The data analysis which is collected through the test analyzed in the following systematic procedure using the formula below.

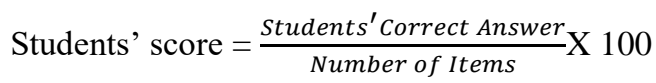

\section{Findings}

\subsection{Students' pre-test and post-test}

The pre-test was given before the students had the treatments. It aimed to find out the students' vocabulary prior knowledge. The order of this test was based on vocabulary purpose. The purpose here means that the students' vocabulary. The researcher prepared questions about vocabulary (noun).

\subsubsection{Pre-test}

The test of pre-test was given before the students doing the treatment. It aimed at finding out the students' vocabulary knowledge. The researcher gave the test by using multiple choice. Before the researcher given the test, the researcher gave clues and clearly explained how to answer the questions. The researcher gave the students 30 minutes to answer the question based on their skill without using a dictionary, but the researcher discovered that some students had trouble answering the questions because they did not understand any of the vocabulary from the test question.. The students' scores in the pre-test were still low. The measured outcome of all the students' scores after taking the pre-test was dominant in some scores, with 13 students classified as bad and two classified as fair. Their pre-test result had a maximum score of 15 points.

The pre-test result showed that some students in second-grade students of SMP YP PGRI 4 Makassar got bad scores. The researcher discovered that 13 students out of a total of 15 had a low test score. There were two students who performed well on the exam out of a total of fifteen students. It means that the students were not mastering vocabulary and the scored is very bad for the standard value of the vocabulary test. It is shown that students lack vocabulary. There were two students as fair of the test from the total students were 15.

\subsubsection{Post-test}

The test of post-test was given after the students doing the treatment. It aimed to find out the students' vocabulary improvement after the students have been 
learned vocabulary by "Colour Me Colours" game. In this test, the researcher tried to know the result value after doing the treatment. It was expected that the students' score of the post-test result was high than the pre-test score result because the researcher had already given the material through "Colour Me Colours" game as a medium in teaching English vocabulary. The researcher gave the test by using multiple choice. Before the researcher given the test, the researcher gave clues and clearly explained how to answer the questions. The researcher gave the students 30 minutes to answer the question based on their ability without a dictionary. Furthermore, the researcher observed that the students enjoyed answering the questions they were given during this examination. The students were aware of the word. They were concentrating on reading the questions that were given to them, and eventually, the students gathered their responses before time ran out.

The research highlighetd that the students' vocabulary has improved, where post-test was categorized as good and pre-test was categorized as poor. It means that the students were considered different after the treatment. The researcher saw that there were five students who are good, there were eight students who are very good, and there were two students who are excellent.

\subsection{Scores Classification, Frequency, and the Rate Percentage of the Students' Pre-Test and Post-Test.}

\subsubsection{Pre-test}

The students' score of the pre-test was classified into some criteria. The criteria are the frequency and percentage table score of the students in the pre-test. The researcher showed the result of the criteria percentage and frequency of the students' score of pretest were showed as in the following table. The pre-test showed that there were 13 of the students $(86,66 \%)$ out of the 15 students classified into "poor" score, 2 of the students $(13,33 \%)$ out of them were classified into "fair" score, and there was none of the classified into "very poor", "fairly good", "good", "very good" and" excellent" scores. From the result, it can be concluded that the student's vocabulary in the pre-test was "poor".

\subsubsection{Post-test}

The students' score of the post-test was classified into some criteria, such as criteria frequency and percentage table score of the students in the post-test. In the post-test score, there was none of the classified into "very poor", "poor", "fair", "fairly good". There were $5(33,33 \%)$ students classified "good" score, 8 $(53,33 \%)$ students were classified into "very good" score, and $2(13,33 \%)$ student of them classified into "excellent" score. From the explanation about the classification above, it can be concluded that the student's vocabulary mastery was improved. The students' vocabulary mastery after the treatment (posttest score) was "very good".

\subsection{The Students' Total score of Pre-test and Post-test, Square of Pre-test and Post-test, Gain and Square of the Gain.}

To obtain the answer to the research question in the previous chapter, the researcher has collected the result from two kinds of tests, namely pre-test and post-test. A pre-test was given to the students before having the treatments, which aimed to know the students' vocabulary mastery, and a post-test was given to the students after having treatments which aimed to know the achievement of the students' vocabulary mastery after they were taught by using "Colour Me Colours" game in increasing the students' vocabulary mastery. The pre-test and post-test were compared to examine whether or not there was a significant achievement of the students' vocabulary mastery. Further, in students pre-test, four students got 40 scores, while in the posttest none, three students got 45 scores, while in posttest none, there were three students 50 scores while in posttest none, there were two students got 55, and there were onestudent got 60 while in post-test none. There was one student who got 65 scores, while in the posttest, none. There was no student who got 80 in per-test, while in post-test was one student got 80 . There was no student who got 85 , while in the post-test, there were four students. There were no students who got 90 scores in the pre-test, while in the post-test, there were students. There were no students who got 95 scores in the pre-test, while in post-test there were four students, and there was none student got 100 scores in the pretest, while in post-test there were two students.

Based on the data explained above, the researcher concluded a significant improvement in students' vocabulary achievement between pre-test and post-test. The pre-test's maximum score was 65 , and the minimum score was 40 , while in the post-test, the maximum score was 100 , and the minimum score was seventy 80 . Furthermore, based on the table above, the researcher had collected the students' scores in pre-test and post-test. In this case, the researcher tries to compare the students' results of pre-test and post-test.

The total score of the pre-test was 735 , from the total number of students were 15 students. It also showed that the student's vocabulary mastery in second-grade students of SMP YP PGRI 4 Makassar was very low. The total score of the post-test was 1360 , from the total number of students were 15 students. It concluded that the result of the post-test was higher than the result of the pre-test. It showed that using "Colour Me Colours" game could increase students' vocabulary mastery at the second-grade students of SMP YP PGRI 4 Makassar. 
The square of the pre-test was 36.875 . It showed that the vocabulary mastery of the students was very low. Besides that, the square of the post-test was 123.800. It means that the vocabulary mastery of the students was very good. It also noticed that using the "Colour Me Colours" game is effective in teaching vocabulary. The total gain or difference between the matched pairs was 625 , and the total score of square gain was 27.275. It showed that the gain was higher between pre-test and post-test. The total score was very significant because the students got a very good score in the post-test than the pre-test scores. In this case, the researcher was a success to apply the material using "Colour Me Colours" game.

\subsection{Mean Score of Students' Pretest and Posttest and Standard Deviation.}

The calculating of the mean score of the students' result in pre-test and post-test and the standard deviation of the students' pre-test and posttest was presented below:

\subsubsection{The mean score of students' pre-test and post-test}

a) Pre-test

$$
\begin{aligned}
& X=\frac{\sum X}{N} \\
& X=\frac{735}{15} \\
& X_{1}=49
\end{aligned}
$$

b) Post-test

$$
\begin{aligned}
& \mathrm{X}=\frac{\sum X}{N} \\
& \mathrm{X}=\frac{1360}{15} \\
& \mathrm{X}_{2}=90,66
\end{aligned}
$$

Based on the data above, the mean score of students' pre-test was 49 from the total score of 735 , and the mean score of students' post-test was 90 from the total score of 1360 . It could be concluded that the mean post-test score was greater than the mean pre-test score.

3.4.2 The standard deviation of student' pre-test and post-test

a) Pre-test

$$
\begin{aligned}
& \mathrm{SD}=\sqrt{\frac{\sum X^{2}-\frac{\left(\sum X\right)^{2}}{N}}{N-1}} \\
& \mathrm{SD}=\sqrt{\frac{36875-\frac{(735)^{2}}{15}}{15-1}} \\
& \mathrm{SD}=\sqrt{\frac{36875-36015}{14}} \\
& \mathrm{SD}=\sqrt{\frac{860}{14}} \\
& \mathrm{SD}=\sqrt{61,42} \\
& \mathrm{SD}=7.83
\end{aligned}
$$

b) Post-test

$$
\begin{aligned}
& \mathrm{SD}=\sqrt{\frac{123800-\frac{(1360)^{2}}{15}}{15-1}} \\
& \mathrm{SD}=\sqrt{\frac{123800-123306.67}{14}} \\
& \mathrm{SD}=\sqrt{\frac{493.33}{14}} \\
& \mathrm{SD}=\sqrt{35.24} \\
& \mathrm{SD}=5.93
\end{aligned}
$$

Based on the data above, the standard deviation of students' pre-test was 1.386, and the standard deviation of students' post-test was 1.117 . It could be concluded that the standard deviation of the post-test score was greater than the standard deviation of the pre-test score. The result of the pretest and posttest after calculating the mean score and standard deviation were presented in the following table:

Table 1. The Mean Score and Standard Deviation of Pre-test and Post-test

\begin{tabular}{lll}
\hline \multicolumn{1}{c}{ Test } & Mean score & $\begin{array}{c}\text { Standard } \\
\text { Deviation }\end{array}$ \\
\hline Pre-test & 49 & 7,83 \\
Post-Test & 90,66 & 5,93 \\
\hline
\end{tabular}

Table 1 showed that the mean score of the students' pre-test was 49, and it showed that the score was in the "fair" classification. The mean score of the students' post-test was 90,66, and it showed that the score was in the "very good" classification. The students' pre-test standard deviation was 7,83, while the standard deviation of post-test was 5,93. From the table above, the researcher can see that the mean score of students' post-test was greater than the mean score of the students' pre-test. Thus, the standard deviation of students' pre-test was higher than the standard deviation of students' post-test, which proved that the range of the students' score was better. This is means that teaching using the "Colour Me Colours" game made students' has improvement.

\subsection{The Significant Difference between Pre-test and Post-test}

In this research, the use of the T-test value was to know the students' significant difference in vocabulary mastery after using "Colour Me Colours" game for students. The T-test in this research also answers the null hypothesis (Ho) after using "Colour Me Colours" game and Alternative Hypothesis (H1). The table was taken at the level of significance $(\mathrm{D})=0.05$ and at the degree of freedom $(\mathrm{df})=14$, so the T-table value was 2.145. In order to know whether or not there is a significant difference between pretest and posttest can be known by using t-test, as follows: Where;

$$
\mathrm{D}=\frac{\sum D}{N}
$$




$$
\begin{aligned}
& \mathrm{D}=\frac{625}{15} \\
& \mathrm{D}=41.67 \\
& \mathrm{t}=\frac{D}{\sqrt{\frac{\sum D^{2}-\frac{\left(\sum D\right)^{2}}{N}}{N(N-1)}}} \\
& \mathrm{t}=\frac{41.67}{\sqrt{\frac{27275-\frac{(625)^{2}}{15}}{15(15-1)}}} \\
& \mathrm{t}=\frac{41.67}{\sqrt{\frac{27275-26041.67}{210}}} \\
& \mathrm{t}=\frac{41.67}{\sqrt{\frac{1233.4}{210}}} \\
& \mathrm{t}=\frac{41.67}{\sqrt{5.87}} \\
& \mathrm{t}=\frac{41.67}{2.42} \\
& \mathrm{t}=17.21
\end{aligned}
$$

Table 2. Distribution of the Value of t-test and t-table

\begin{tabular}{cc}
\hline T-test & T-table \\
\hline 17.21 & 2.145 \\
\hline
\end{tabular}

According to the table above, the level of significance $(\alpha)=0.05$ and degree of freedom $(\mathrm{df})=$ 14. Then the value of t-table $=2.145$ and $t$-test $=17.21$. Thus the value of the t-test was higher than the t-table $(17.21>2.145)$. So, the result of the T-test above showed that there was a significant difference between pre-test and post-test after using treatment by Using "Colour Me Colours" game. It could be summarized that the T-test value was higher than the T-table value $(17.21>2.145)$ at the level of significant 0.05 . Based on the data in the table above, the value of the t-test has been shown to be higher than the value of the t-table. It could be concluded that there were different results in teaching vocabulary between the students' pre-test and post-test value by Using "Colour Me Colours" game.

\subsection{Hypothesis Testing}

After finding out the t-test value is 17.12, determining the $\mathrm{t}$ table value to know whether pre-test and post-test are significantly different. In determining the t-table value, firstly, find out the degree of freedom (df). The researcher used the following formula:

$$
\begin{aligned}
& \text { df }=N-1 \\
& =15-1 \\
& =14
\end{aligned}
$$

For the level of significance $(\alpha)=0.05$ and degree of freedom $(\mathrm{df})=14$. Then the value of $\mathrm{t}$-table $=2.145$ and t-test $=17.12$. Compared to the test value, it can be concluded that the t-test value (17.12) was higher than the t-table (2.145). On the other hand, we said that $17.12>2.145$. It means that the null hypothesis (H0) of this research is rejected, and the alternative hypothesis (H1) is acceptable because there is a significant difference between the pre-test and post-test result by colour me colour game for increasing students vocabulary mastery. From the analysis above, the researcher concludes that there was a significant achievement towards students' vocabulary mastery by using "Colour Me Colours" game at the second-grade of SMP YP PGRI 4 Makassar.

\section{Discussion}

The sample of this research was class 2, they were collected by purposive sampling technique, and the data was collected by the vocabulary that used multiple choice. The researcher used the "Colour Me Colours" game as treatment in this research as a method in teaching English vocabulary. According to Leahy (2011), in the inside scoop on teaching English in East Asia, Sprite Game is a writing practice intended to teach children vocabulary. It means that the "Colour Me Colors" game can be used as one of the tools to help students develop their vocabulary mastery. This is a fun and successful game that can be used to teach and practice vocabulary words. Students are given the opportunity to learn the four skills of reading, writing, listening, and speaking.

"Colour Me Colours" is a game where students can learn while playing, splitting into groups and competing to become winners. As a result, the use of games in learning is a practice that teachers should be delighted with because games are enjoyable learning experiences for students.

To collect the data and find out the questions answered in the previous chapter's problem statement, the pre-test and post-test were applied. The pre-test was administered before giving the treatment to measure the students' prior knowledge of vocabulary mastery. It was followed by 15 students for 30 minutes. The researcher distributed the material test and asked the students to answer the question based on their ability. After giving the pre-test, the students were given the "Colour Me Colours" game treatment in teaching English vocabulary.

The treatment was carried out for four meetings. The treatment was begun on December 17th 2020, and finished on January 23th 2021Every meeting lasted 60 minutes in the classroom, and the students did not wear school uniforms because, at the time, the teacher and students were discouraged from developing a process for teaching and learning at school due to COVID-19 disease. So, the researcher gathered the first-grade students of SMP YP PGRI 4 Makassar in a class of Junior High School because I think that the place was secure. I used the time during 40 days in this research 
it was caused I took the time afternoon ( $3.00 \mathrm{pm})$ to not interfered with the students' time to study at home, and the students, the teacher and their parents also agree.

The researcher encountered some difficulties, especially when conducting meetings, because the students believe that the meeting is not formal, and they also did not understand what the researcher meant and explained the instruction in English. As a result, the researcher mixed English and Indonesian..

The first meeting: the researcher introduces herself and require the students to introduce themselves. After that, the researcher explained the purpose of this research. Besides that, the researcher explains to the students what they would to do in the first meeting until the last meeting and what they would achieve after studying. After they understood the explanation, the researcher gives a pre-test to students to value the students' ability about their vocabulary mastery. After that, the researcher continued to teach about the noun.

In the second meeting, the researcher introduced the vocabulary game, and it was the "Colour Me Colours" game. In this case, the researcher explained what "Colour Me Colours" game, the steps and how to play the "Colour Me Colours" game is. After the researcher explained about "Colour Me Colours" game, the researcher showed that game to the students. After that, the researcher guided the students to make groups, and each group consisted of four students. Next, the researcher asked the students to stand based on their groups, and the students start to play the game. The researcher instructed each group's students, and then the teacher will say a word, and the students listen to what the teacher says carefully.

After that, the teacher instructed two students to stand in front of the class and then one of them stick the coloured card to the word said by the teacher on the part of his friend's body. After they stick the coloured card on the part of their friend's body, they spell and say it in front of their friends. The teacher knows the winner by listening to the first one who spelt and said the word correctly. Same as the previous meetings, a student who is the winner got the point for their team. And the game ends when each student from each team has his chance, and there is one team as the winner.

The won of this game was the teams could guess the high score. The second meeting: the researcher prepared materials about a family tree. After that, the researcher guided the students to make groups, and each group consisted of four students. Following that, the researcher asked the students to stand according to their groups, and the students began playing the game.

The researcher instructed the students in each group, then, the teacher said something, and the students paid close attention to what the teacher said. After that, the teacher instructed two students to stand in front of the class, one of them stick the coloured card to the word said by the teacher on the part of the body of his friend. After they stick it on the part of their friend's body, they spelt and said it in front of their friends. The teacher knows the winner by listening to the first one who spelt and said the word correctly. As in previous meetings, the winning student earned a point for their squad. The game ends when each student from each team has had their turn, and one team is declared the winner. This game was won by the teams who correctly predicted the highest score.

The third meeting of the treatment: the researcher gave material about the kinds of an adjective, the researcher divided the students into four (4) groups, each group members of 5 students, and then the researcher gave an explanation of the rules of the game, Sprite game. The researcher then asked the students to take their seats according to their classes, and the students began playing the game. The researcher gave each group of students an instruction, then the teacher said something, and the students paid close attention to what the teacher said. One student from each team raced to the blackboard or whiteboard to write the word said by the teacher. After they have written the word, they spell and say it in front of their friends. The teacher knows the winner by listening to the first one who spelt and said the word correctly. It is similar to the previous meetings, the winner got the point for their team and the game ends when each student from each team has his chance, and there is one team as the winner. The won of this game was the teams could guess the high score.

The fourth meeting of the treatment: the students also played the "Colour Me Colours" game, but the material was not only one kind but about all that has been learned in the previous meetings. And during the students doing the game, the researcher controlled and gave guidance to them. The won of this game was the teams could guess high points.

At the last step, the researcher gave a post-test after gave the treatment. The researcher gives the students a post-test used the vocabulary test. The researcher delivered the test and asked the students to answer the questions. The test and number of item in post-test was the same as the pre-test. The test consists of two parts questions, and the test takes time around 30 minutes.

After having the data of pre-test and post-test, the researcher compared the students' result of pre-test and post-test. It was aimed to find out whether or not there was a significant difference between the result of pretest and post-test. In other words, whether the result of the post-test was higher than the pre-test. And the following is the details of the finding discussion of this research. To know the effect of "Colour Me Colours" game on students in learning English process and teaching English vocabulary. 
The discussion deals with the interpretation of the findings derived from the data analysis the description of the data collected through vocabulary test, which explained in the previous part, which showed that the students' vocabulary achievement were increased. It was supported by the result of the frequency and rate percentage of the students' pre-test and post-test. The students score after presenting material by using the "Colour Me Colours" game in teaching and learning vocabulary test was better than before the treatment was given to them.

The following is a brief discussion of the students' pre-test and post-test results. According to the data, both pre-test and post-test, the students' abilities improved after the treatment. The highest score of pretest score the students got in pre-test was 55 (it is only three students) categorized poor score while the highest score the students got in post-test was 100 as categorized excellent after doing the treatment had given. It means that the application "Colour Me Colours" game in teaching and learning vocabulary could improve the students' achievement from poor scores to excellent scores.

The description of the data collected through vocabulary test in the previous section shows that the students' English vocabulary improved. It was supported by the frequency and the rate percentage of the students' pre-test and post-test. The students' score after doing treatment by "Colour Me Colours" game in teaching and learning vocabulary was higher before the treatment given to the students.

The mean score of the students' post-test was higher $(90,66)$ than the students' pre-test $(49)$. It means that the null hypothesis (H0) of this research was rejected, and the alternative hypothesis (H1) was accepted because there was a significant difference between students pre-test and post-test by "Colour Me Colours" game in teaching vocabulary.

Based on the comparison of the data score pre-test and post-test before, it could be concluded that the classification of pre-test dominant in average classifications and in post-test was dominant in very good classification. So it could be inferred that there was a significant difference between students pre-test and post-test result.

Another case demonstrated that rising students' vocabulary mastery was also demonstrated by the importance of the t-test. The t-test for this analysis was 17.21, and the t-table was 2,145. It clarified that the $\mathrm{t}$ test value was greater than the t-table value, and it was concluded that there was significance between the students' pre-test and post-test results. Using "Colour Me Colours" game in teaching and learning vocabulary was effective in increasing the students' vocabulary mastery.
The average of students' score in pre-test and posttest plays an important role in determining the success of a technique used in teaching and learning vocabulary. Logically, if the average students' score in the pre-test is higher than the average score of the posttest, we can conclude that the technique used does not have a significant influence on increasing students' English vocabulary. Automatically the technique cannot be used in increasing the students' vocabulary achievement. On the contrary, if the average students' score in the pre-test is lower than the average of students' post-test score, we can conclude that the technique used has a significant influence in increasing students' vocabulary achievement.

During the treatment, the researcher identified some problems. First, students were noisy because the students learned vocabulary by using a game. However, the students participated actively and enjoyed the teaching and learning process. They showed their enthusiasm and interest in learning vocabulary by using the game. Second, they could not understand what the researcher explained the instruction in English. Therefore, the researcher combined English and the Indonesian language.

These findings supported the statement about the advantages of using the "Colour Me Colours" game to learn vocabulary: (1) It does not use a monotonous activity, (2) It is fun for students, (3) It helps the students learn and acquire new word early, (4) It involves friendly competition and keeps students interest, (5) It serves students to learn to pronounce and spell words, (6) The students more active that teacher. This research found that using gamification can increase students' vocabulary mastery. In the brief of the discussion above, the use of the "Colour Me Colours" game was good enough to increase the students' vocabulary, especially in the vocabulary of the noun. It could be proved by seeing the increase in students' pre-test and post-test score. Thus, it indicates that the second-grade students of SMP YP PGRI 4 Makassar increase their vocabulary ability, especially by using "Colour Me Colours" game.

\section{Conclusion}

Based on the result of the discussion, it could be concluded that an effective way of teaching vocabulary by using the "Colour Me Colours" Game could be achieved by giving motivation for students in learning It can be seen from the post-test mean score (90.66), which is higher than the pre-test mean score (49). This present study also highlighted that most of the students enjoy the teaching and learning process. The researcher could say that research success to apply at the secondgrade of SMP YP PGRI 4 Makassar. They were active in the classroom because of the "Colour Me Colours" game. Also, they already master new words and memorize them quickly. Generally, the researcher 
concluded that the "Colour Me Colours" game in teaching vocabulary make the students easy to understand the material. The situation of the teaching and learning process becomes enjoyable and interesting.

\section{References}

Aydoğan, H., \& Akbarov, A. A. (2014). The four basic language skills, whole language $\&$ intergrated skill approach in mainstream university classrooms in Turkey. Mediterranean Journal of Social Sciences, 5(9), 672-672.

Brown, H. D., \& Lee, H. (1994). Teaching by principles: An interactive approach to language pedagogy (Vol. 1, p. 994). Englewood Cliffs, NJ: Prentice Hall Regents.

Depdiknas, (2003). Undang Undang Republik Indonesia No. 20 Tahun 2003 Tentang System Pendidikan Nasional. Bandung: Citra Umbara. On.

Febriyansyah, I. (2016). Improving students' vocabulary mastery through Bingo game for grade $\mathrm{X}$ of SMAN 4 Purworejo in the academic year of 2014/2015. English Language Teaching Journal, 5(3).

Gairans, R. and Redman, S. (1986). Working With. a Guide to Teaching and Learning Vocabulary. Washington DC. Cambridge University Press.

Goodman, D. J., \& Mohr, C. (1997). Building Vocabulary Skills. Townsend Press.

Harmer, J. (2001). The practice of English language teaching. Longman.

Imas. F. (2018). Improving Students' Vocabulary Mastery Through Bingo Game For Grade X of SMAN 4 Purworejo. A Thesis in UNY

Iriyani, A. (2008). Increasing the Students' English Vocabulary of SDN PAI using realia. Thesis Makassar: STKIP-YPUP

Karmila, F. (2008). The Use of Picture Based Activities to Improve the First Year Students' Speaking Proficiency at MA Madani Alauddin Pao-Pao. Unpublished Thesis.

Lauder, A. (2008). The status and function of English in Indonesia: A review of key factors. Makara Hubs-Asia, 12(1), 9-20.

Lo, Y. Y., Anderson, A. L., \& Bunch-Crump, K. (2017). Building vocabulary of English learners with reading disabilities through computerassisted morphology instruction. Intervention in School and Clinic, 52(3), 133-140.

Lubis, I. R. (2017). Improving students' vocabulary mastery by using fly swatter game in the first grade of MTS PERSATUAN AMAL BAKTI (PAB) 1 HELVETIA (Doctoral dissertation, Universitas Islam Negeri Sumatera Utara).

Mariangga, R. (2012). Improving The students' Vocabulary Through Bookworm Game At The Second Grade Of SMP Tamalatea Makassar". Thesis. STKIPtkip Ypup

Nurmiati. (2004). “Improving the students' English Vocabulary Mastery by Using Game Method“" Thesis Faculty of Language and Arts UNM.

Pajo, M. N. (2017). Using games to improve vocabulary knowledge of the eleventh grade students of senior high school. Unpublished bachelor's thesis]. Universitas Sanata Dharma Yogyakarta.

Polem, A. M. (2017). The implementation of simon say game to improve students' vocabulary mastery in learning english at mts. laboratorium UIN-SU Medan (Doctoral dissertation, Universitas Islam Negeri Sumatera Utara)

Prasetyo. (2018). The Effect of Color Game to The Students Vocabulary Mastery.

Rasyid, M. A., \& Nur, H. J. (1997). Teaching English as a Foreign Language in Indonesia: Theory, Practice, and Research. FBS IKIP Ujung Pandang.

Sengi, A. (2019). Imimproving tudents' Vocabulary Mastery by Using English Program on "telebram" at the Third-Grade Students of SMP Negeri 1 Bontoramba. THESIS OF STKIP YPUP Makassar.

Wallace, M. J. (1982). Teaching vocabulary (Vol. 10). Heinemann.

Wulanjani, A. N. (2016). The Use of VocabularyGames in Improving Children's Vocabulary in English Language Learning. Transformatika: Jurnal Bahasa, Sastra, dan Pengajarannya, 12(1), 76-83.

Yerkes, D. (1994). Webster's encyclopedia unabridged dictionary. 